\title{
PENGARUH ENVIRONMENTAL PERFORMANCE DAN ENVIRONMENTAL DISCLOSURE TERHADAP ECONOMIC PERFORMANCE
}

\author{
Danny Widarto \\ Universitas Muhammadiyah Purwokerto \\ Rina Mudjiyanti \\ Universitas Muhammadiyah Purwokerto
}

\begin{abstract}
The aim of this research was to examine the influences of the environmental performance and environmental disclosure to the economic performance. This research focused on the public companies complying with PROPER KLH RI in the period of 2010-2012. The sample was 35 companies. The data were then analyzed using multiple lineali ${ }^{1}$ regressions. Based on the analysis, it was proved that the environmental performance partially had significant effect to the economic performance. Meanwhile, the environmental disclosure partially had no significant effect to the economic effect. Yet, simultaneously both environmental performance and environmental disclosure influenced significantly to the economic performance, meaning the concept of environmental accounting begins to have Indonesian public acceptance. The model of environmental accounting has improved and influenced the economic performance.
\end{abstract}

Keywords: environmental accounting, environmental performance, environmental disclosure, and economic performance.

\section{I.PENDAHULUAN}

Permasalahan lingkungan semakin menjadi perhatian baik oleh pemerintah, konsumen maupun investor. Ketika kedaulatan pasar tidak dapat dikontrol oleh kedaulatan rakyat secara baik maka kemiskinan akan semakin meluas, karena kebijakan publik yang ada tidak memihak pada kepentingan rakyat. Hal itu juga akan terjadi bilamana kekuatan pasar global tidak dapat lagi diatur dan dikendalikan oleh suatu negara, maka akan banyak kepentingan nasional yang terabaikan termasuk diantaranya adalah upaya perlindungan pelestarian lingkungan. Salah satu tujuan perusahaan dalam mengungkapkan kinerja lingkungan, sosial dan finansial di dalam laporan tahunan atau laporan terpisah adalah untuk mencerminkan tingkat akuntabilitas, responsibilitas dan transparansi korporat kepada investor. Pengungkapan tersebut bertujuan untuk menjalin hubungan komunikasi yang baik dan efektif antara perusahaan dengan publik dan stakeholder lainnya tentang bagaimana perusahaan telah mengintegrasikan CSR dan lingkungan sosial dalam setiap kegiatan operasinya (Darwin, 2007).

Indonesia mengalami permasalahan pencemaran lingkungan seperti seperti halnya negaranegara yang lain. Berbagai pencemaran dan kerusakan lingkungan ditengarai disebabkan oleh operasionalisasi mesin dan teknologi yang digunakan sejumlah perusahaan untuk meraih keuntungan komersial dalam jumlah besar (Dharma, C.A., 2012). Masalah ini tidak terjadi jika para manajer perusahaan memegang komitmen pada pemenuhan tanggung jawab sosial terhadap kebersihan 
lingkungan. Usaha dari pihak regulasi untuk melestarikan dan mengembangkan kemampuan lingkungan hidup yang serasi, selaras, dan seimbang telah dilakukan dengan menetapkan UndangUndang Republik Indonesia nomor 23 tahun 1997 tentang pengelolaan lingkungan hidup. Aturan pelaksanaan lebih lanjut telah dinyatakan dengan diterbitkannya Peraturan Pemerintah nomor 18 tahun 1999.

Al-Tuwaijri, et al. (2004) menemukan adanya hubungan positif signifikan antara economic performance dengan environmental performance demikian juga antara environmental disclosure dengan environmental performance. Suratno, Darsono dan Mutmainah (2006) menemukan adanya pengaruh positif signifikan antara environmental performance terhadap environmental disclosure, dan adanya pengaruh positif signifikan antara environmental performance terhadap economic performance. Almilia dan Wijayanto (2007) menemukan adanya pengaruh signifikan dalam pengujian hubungan antara environmental disclosure dengan economic performance, dan tidak adanya hubungan signifikan antara environmental performance dengan economic performance. Rahmawati dan Achmad (2012) menemukan tidak adanya pengaruh signifikan antara kinerja lingkungan dengan financial corporate performance, kemudian ada hubungan positif signifikan antara kinerja lingkungan dengan CSR disclosure, serta adanya pengaruh secara simultan antara kinerja lingkungan dan CSR disclosure terhadap financial corporate performance. Penelitian-penelitian empiris tersebut menampakan hasil yang masih banyak terdapat perbedaan.

\section{II.TINJAUAN PUSTAKA}

\section{Teori Legitimasi (Legitimacy Theory)}

Legitimacy theory secara esensial adalah teori yang berorientasi pada sistem, dalam hal ini organisasi atau perusahaan di pandang sebagai salah satu komponen lingkungan sosial yang lebih besar. Teori legitimasi menyatakan bahwa suatu organisasi hanya bisa bertahan jika masyarakat di sekitar lingkungan organisasi merasa bahwa organisasi beroperasi berdasarkan sistem nilai yang sepadan dengan sistem nilai yang dimiliki oleh masyarakat (Zaenuddin, 2007).

\subsection{Sustainable Development}

Tujuan dari sustainable development adalah untuk memenuhi kebutuhan generasi sekarang tanpa mengurangi kemampuan generasi yang akan datang dalam memenuhi kebutuhan mereka. Sebagai kekuatan penting pada masyarakat, organisasi dalam bentuk apapun memiliki sebuah peran penting dalam pencapaian tujuan ini. Salah satu tantangan utama dari sustainable development adalah adanya tuntutan akan pilihan-pilihan dan cara berpikir yang baru dan inovatif. Perkembangan pengetahuan dan teknologi dituntut tidak hanya memberikan kontribusi terhadap pertumbuhan ekonomi, tetapi juga dapat membantu dalam memecahkan permasalahan terkait risiko dan ancaman terhadap keberlanjutan dari hubungan sosial, lingkungan, dan perekonomian. (GRI reporting guidelines, 2000). 


\subsection{Environmental Accounting}

Konsep ini terbentuk sebagai akibat dari persepsi bahwa perusahaan perannya tidak sematamata hanya tentang produktifitas dan tentang perolehan keuntungan saja, tetapi sebenarnya dalam setiap aktivitas bisnis terdapat tanggung jawab dan tujuan sosial serta tanggung jawab lingkungan yang harus dilakukan secara baik oleh perusahaan terhadap masyarakat dan lingkungannya (Rahahleh, 2011). Sistem ini berfungsi untuk mengisi kebutuhan informasi di bidang environmental performance perusahaan. Dari sudut pandang pengguna, environmental accounting harus memenuhi kebutuhan informasi pengguna internal atau eksternal (stakeholders) (Hyrslova dan Hajek , 2006).

\subsection{Pengaruh environmental performance dan environmental disclosure terhadap economic performance.}

Berdasar pada penelitian-penelitian sebelumnya beserta teori yang mendasari penelitian tersebut. Peneliti merasa perlu untuk melakukan pengujian secara simultan antara variabel independen yaitu environmental performance dan environmental disclosure terhadap variabel dependen economic performance. Ini dilakukan bertujuan untuk mengetahui pengaruh secara simultan antara variabel independen terhadap variabel dependen, apakah terdapat pengaruh signifikan bila dilakukan pengujian secara simultan.

$\mathrm{H}_{1}$ : Environmental performance dan environmental disclosure secara simultan berpengaruh signifikan terhadap economic performance.

\subsection{Pengaruh environmental performance terhadap economic performance.}

Jika polusi lingkungan mengakibatkan efek penurunan kinerja sumber daya perusahaan menjadi tidak efektif dan kurang efisien, maka pengelolaan limbah dan manajemen polusi lingkungan perlu dilakukan untuk memberi manfaat bagi perusahaan dan lingkungannya (Porter dan Linde, 1995). Narver (1971) penganut konsep hubungan yang saling melengkapi ini percaya bahwa bertindak pada suatu tanggung jawab sosial perusahaan akan mengurangi resiko pada saat pasar modal makin bertambah sensitif.

$\mathrm{H}_{2}$ : Environmental performance secara parsial berpengaruh signifikan terhadap economic performance.

\subsection{Pengaruh environmental disclosure terhadap economic performance.}

Informasi laporan keuangan perusahaan berperan penting dalam pasar modal, baik bagi investor secara individual maupun bagi pasar secara keseluruhan. Investor memerlukan informasi untuk dasar pengambilan keputusan dan pasar memanfaatkan informasi untuk mencapai harga keseimbangan baru yang lebih baik dari sebelumnya.

$\mathrm{H}_{3}$ : Environmental disclosure secara parsial berpengaruh signifikan terhadap economic performance. 


\section{III.METODE PENELITIAN}

\subsection{Populasi, Sampel dan Tehnik Pengambilan Sampel}

Populasi dalam penelitian ini adalah perusahaan publik peserta PROPER KLH RI yang terdaftar di Bursa Efek Indonesia tahun 2010-2012. Sampel penelitian ini diambil dengan teknik purposive sampling dengan tujuan agar diperoleh sampel yang representatif sesuai dengan kriteria yang ditentukan. Adapun kriteria sampel adalah sebagai berikut: Perusahaan publik peserta PROPER $\mathrm{KLH}$ RI, dan menerbitkan laporan tahunan untuk periode 2010-2012. Adapun hasil sampel akhir perusahaan adalah 35 perusahaan.

\subsection{Data dan Metode Pengumpulan Data}

Jenis data yang digunakan dalam penelitian ini adalah data sekunder dalam bentuk kuantitatif yaitu data perusahaan go public yang diperoleh melalui website Bursa Efek Indonesia yaitu www.idx.co.id. sedangkan data yang memuat informasi hasil PROPER diperoleh melalui database Kementrian Lingkungan Hidup Republik Indonesia. Data-data yang diperlukan untuk penelitian ini antara lain: daftar perusahaan publik peserta PROPER KLH RI, informasi environmental disclosure dalam laporan tahunan (annual report), serta informasi harga saham perusahaan. Pengumpulan data yang dilakukan dalam penelitian ini adalah metode dokumenter, karena data yang dikumpulkan adalah data sekunder yang diperoleh melalui website www.idx.co.id dan database Kementrian Lingkungan Hidup Republik Indonesia yaitu data laporan tahunan (annual report) dan data hasil penilaian PROPER.

\subsection{Definisi Operasional Variabel dan metode analisis}

\subsubsection{Economic Performance (Y)}

economic performance merupakan gambaran kinerja perusahaan-perusahaan secara relatif dalam suatu bentuk industri yang sama ditandai dengan return tahunan saham industri bersangkutan sebagai tolak ukurnya (Suratno, Darsono dan Mutmainah, 2006). Menurut Al-Tuwaijii, et al. (2003) penelitian-penelitian sebelumnya menggunakan ukuran accounting-based dan market-based untuk mempresentasikan economic performance, pada penelitian ini digunakan ukuran market-based untuk mempresentasikan economic performance yaitu dengan cara menggunakan industry-adjusted annual return yang didasarkan pada perhitungan selisih antara annual stock return dengan median dari 
kumpulan data annual stock return yang dianggap mampu mempresentasikan economic performance secara lebih objektif dan komprehensif. Economic performance dinyatakan dalam skala yang dihitung:

Dimana:

$$
\mathrm{ECP}=\frac{\left(P_{1}-P_{0}\right)+\text { Div }}{P_{0}}-M e_{R I}
$$

- EcP : Economic performance (kinerja ekonomi)

- $P_{1} \quad$ : Harga saham akhir tahun,

- $P_{0} \quad$ : Harga saham awal tahun,

- Div : Pembagian deviden,

- $M e_{R I}$ : Median return saham tahunan (annual stock return median).

\subsubsection{Environmental Performance $\left(\mathrm{X}_{1}\right)$}

Environmental performance perusahaan menurut Suratno, dkk (2006) adalah kinerja perusahaan dalam membentuk lingkungan yang baik (green). Di ukur atas prestasi perusahaan peserta PROPER KLH RI, yang mencakup pemeringkatan perusahaan dalam lima (5) warna yang akan diberi skor secara berturut-turut dengan nilai tertinggi 5 untuk warna emas dan terendah 1 untuk warna hitam. Adapun sistem skoring pemeringkatan environmental disclosure adalah sebagai berikut:

\begin{tabular}{ll}
\hline WARNA & SKOR \\
\hline Emas & 5 \\
Hijau & 4 \\
Biru & 3 \\
Merah & 2 \\
Hitam & 1 \\
\hline
\end{tabular}

\subsubsection{Environmental Disclosure $\left(\mathrm{X}_{2}\right)$}

Environmental disclosure adalah pengungkapan informasi yang berkaitan dengan lingkungan di dalam laporan perusahaan (Suratno, Darsono dan Mutmainah, 2006). Hal tersebut dapat diketahui dengan perumusan sebagai berikut:

$$
\mathrm{EnD}=\frac{\text { Jumlah yang dilaporkan pada tahun ke }-\mathrm{n}}{\text { Jumlah yang wajib dilaporkan }} \times 100 \%
$$

\subsection{Metode Analisis}

Teknik analisis data yang digunakan dalam penelitian ini adalah analisis regresi berganda. Untuk mengetahui kekuatan pengaruh variabel independen terhadap variabel dependen.

Economic performance $=$ (environmental performance + environmental disclosure $)$

$$
\mathrm{EcP}=\alpha_{0}+\beta_{1} \operatorname{EnP}+\beta_{2} \operatorname{EnD}+\varepsilon_{1}
$$


Keterangan:

$\mathrm{EcP} \quad=$ economic performance (kinerja ekonomi yang dicapai)

$\mathrm{EnP} \quad=$ environmental performance (kinerja lingkungan perusahaan)

$\mathrm{EnD}=$ environmental disclosure (pengungkapan lingkungan)

$\alpha_{0}, \quad=$ Intercept (parameter)

$\beta_{1} \cdots \mathrm{n},=$ Koefisien regresi

\section{HASIL DAN PEMBAHASAN}

Jumlah perusahaan publik yang menjadi emiten di Bursa Efek Indonesia (BEI) hingga Oktober 2013 adalah 480 perusahaan. Sejumlah 35 perusahaan memenuhi kriteria sampel, sedangkan 445 perusahaan tidak memenuhi kriteria sampel.

\subsection{Ananlisis Deskriptif}

Tabel 1

\begin{tabular}{llllll}
\hline & $\mathrm{N}$ & Minimum & Maximum & Mean & Std. Deviation \\
\hline EnP & 105 & 1 & 5 & 3.35 & .784 \\
$\mathrm{EnD}$ & 105 & .000 & 1.000 & .25886 & .216730 \\
$\mathrm{ECP}$ & 105 & -1.093 & 7.647 & .16391 & 1.102238 \\
Valid N (listwise) & 105 & & & & \\
\hline
\end{tabular}

Berdasar tabel 1 diatas, diketahui data penelitian berjumlah 105. Besarnya rata-rata variabel environmental performance (EnP) sebesar 3,35, jika diperingkatkan kedalam PROPER adalah berada pada peringkat biru. Nilai environmental performance terendah adalah 1 (satu), dan nilai tertingginya adalah 5 (lima). Sampel penelitian dengan nilai environmental performance terendah adalah JPRS 2010 dengan nilai 1 (satu), satu (hitam) dalam masalah lingkungan berarti perusahaan sangat buruk/kurang memperhatikan pengelolaan dan manajemen lingkungannya. Sedangkan sampel penelitian dengan nilai environmental performance tertinggi yaitu 5 adalah: ADRO 2012, INTP 2012, SMCB 2010-2012, SMGR 2012, dan UNVR 2012.

Sedangkan besar rata-rata untuk variabel environmental disclosure (EnD) adalah sebesar 0,2588, hasil ini menunjukan bahwa rata-rata environmental disclosure pada perusahaan publik peserta PROPER di Indonesia masih kurang baik. Hal ini terjadi karena penyusunan informasi environmental disclosure dalam laporan tahunan (annual report) perusahaan sampel belum sepenuhnya menggunakan standar pelaporan GRI secara konsisten. Sampel dengan nilai environmental disclosure 1 adalah TINS 2010 \& 2012, sedangkan environmental disclosure terendah adalah 0 yang berarti tidak ada satupun item environmental disclosure yang diungkapkan pada laporan tahunan (annual report) industri sampel penelitian. Sampel dengan nilai environmental disclosure 0 adalah: SRSN 2010 \&2011, JPRS 2012. 
Nilai rata-rata variabel economic performance adalah 0,1639 dengan nilai tertinggi yaitu 7,647 yang diperoleh IMAS 2010 dan nilai terendahnya yaitu ASII 2012 dengan nilai -1,095.

\subsection{Uji Asumsi Klasik}

\subsubsection{Uji Normalitas}

Tabel 2

\begin{tabular}{|c|c|c|}
\hline & & $\begin{array}{l}\text { Unstandardized } \\
\text { Residual }\end{array}$ \\
\hline $\bar{N}$ & & 93 \\
\hline \multirow[t]{2}{*}{ Normal Parameters ${ }^{a}$} & Mean & .0000000 \\
\hline & Std. Deviation & .40421205 \\
\hline \multirow[t]{3}{*}{ Most Extreme Differences } & Absolute & .057 \\
\hline & Positive & .057 \\
\hline & Negative & -.039 \\
\hline Kolmogorov-Smirnov Z & & .552 \\
\hline Asymp. Sig. (2-tailed) & & .920 \\
\hline
\end{tabular}

Berdasar tabel 2 diatas diperoleh nilai statistik kolmogorov-smirnov 0,552 dan asymp. Sig, (2tailed) $>0.05$ yaitu sebesar 0,920 yang berarti data residual terdistribusi normal, artinya variabel variabel penelitian dianggap layak untuk dilakukan analisis regresi berganda.

\subsubsection{Uji Multikolinearitas}

Tabel 3

\begin{tabular}{llll}
\hline & & \multicolumn{2}{l}{ Collinearity Statistics } \\
\cline { 3 - 4 } Model & & Tolerance & VIF \\
\hline 1 & EnP & .977 & 1.024 \\
& EnD & .977 & 1.024 \\
\hline
\end{tabular}

Asumsi yang disyaratkan untuk tidak terjadinya gejala multikolinearitas bila nilai $\mathrm{VIF}<10$ dan nilai tolerance $>0.10$. dari analisis yang terlihat pada tabel 3 di atas, semua variabel independen mempunyai nilai VIF lebih kecil dari 10, dan nilai tolerance lebih besar dari 0,10 . sehingga persamaan regresi telah terbebas dari multikolinearitas (Ghozali, 2011). 


\subsubsection{Uji Heteroskedastisitas}

Tabel 4

\begin{tabular}{|c|c|c|c|c|c|c|}
\hline \multirow[b]{2}{*}{ Model } & & \multicolumn{2}{|c|}{ Unstandardized Coefficients } & \multicolumn{2}{|l|}{$\begin{array}{l}\text { Standardized } \\
\text { Coefficients }\end{array}$} & \multirow[b]{2}{*}{ Sig. } \\
\hline & & $B$ & Std. Error & Beta & $\mathrm{T}$ & \\
\hline \multirow[t]{3}{*}{1} & (Constant) & .575 & .117 & & 4.919 & .000 \\
\hline & EnP & -.065 & .033 & -.201 & -1.940 & .056 \\
\hline & EnD & -.106 & .113 & -.097 & -.941 & .349 \\
\hline
\end{tabular}

Asumsi yang disyaratkan untuk tidak terjadinya gejala heteroskedastisitas bila nilai sig. (signifikansi) lebih besar dari 0,05. Dari analisis yang terlihat pada tabel 4 di atas, semua variabel independen mempunyai nilai sig. lebih besar dari 0,05 sehingga persamaan regresi telah terbebas dari heteroskedastisitas.

\subsubsection{Uji Autokorelasi}

Tabel 5

\begin{tabular}{ll}
\hline Model & Durbin-Watson \\
\hline 1 & 2.081 \\
\hline
\end{tabular}

Berdasar hasil pengujian di atas terlihat bahwa hasil regresi dengan level siginifikansi 0,05 $(a=0.05)$ dengan jumlah variabel independen $2(k=2)$ dan banyaknya data $93(n=93)$ di dapat nilai durbin-watson sebesar 2,081, sedangkan nilai tabel du sebesar 1,703 dan 4-du sebesar 2,297. Agar terbebas dari autokorelasi maka nilai $d u<d<4$-du nilai tersebut yaitu $1,703<2,081<2,297$, berarti terbebas dari autokorelasi

\subsection{Analisis Regresi Linear Berganda}

Tabel 6

\begin{tabular}{lllllll}
\hline \multicolumn{5}{c}{} & \multicolumn{5}{c}{ Unstandardized Coefficients } & $\begin{array}{l}\text { Standardized } \\
\text { Coefficients }\end{array}$ & & \\
\cline { 3 - 5 } Model & & $\mathrm{B}$ & Std. Error & Beta & $\mathrm{t}$ & Sig. \\
\hline 1 & (Constant) & -.546 & .203 & & -2.694 & .008 \\
& EnP & .153 & .058 & .269 & 2.640 & .010 \\
& EnD & -.303 & .195 & -.158 & -1.551 & .124 \\
\hline
\end{tabular}

Berdasar hasil uji regresi berganda pada tabel 6 dapat dilihat koefisien untuk persamaan regresi dalam penelitian ini yang dapat disusun dalam persamaan matematis sebagai berikut:

$$
E c P=-0,546+0,153 E n P-0,303 E n D+e
$$


Persamaan tersebut dapat diartikan:

- Nilai konstanta menunjukan angka -0,546, hal ini berarti apabila semua variabel independen (environmental performance dan environmental disclosure) bernilai 0 , maka nilai economic performance sebesar $-0,546$.

- Nilai koefisien variabel environmental performance sebesar 0,153 , hal ini berarti bahwa setiap terjadi peningkatan environmental performance sebesar 1\% maka akan meningkatkan economic performance sebesar $0,153 \%$.

- Nilai koefisien variabel environmental disclosure sebesar $-0,303$, hal ini berarti bahwa setiap terjadi peningkatan environmental disclosure sebesar $1 \%$ maka akan menurunkan economic performance sebesar $0,303 \%$.

\subsubsection{Uji Koefisien Determinasi (Adjusted $R^{2}$ )}

\begin{tabular}{llll} 
& \multicolumn{2}{c}{ Tabel 7} \\
\hline Model & $\mathrm{R}$ & $\mathrm{R}$ Square & Adjusted R Square \\
\hline 1 & $.291^{\mathrm{a}}$ & .085 & .064 \\
\hline
\end{tabular}

Berdasarkan tabel 7 bahwa koefisien determinasi yang menunjukan nilai adjusted $r$-square sebesar 0,064, artinya variabel environmental performance dan environmental disclosure berpengaruh terhadap economic performance sebesar $6,4 \%$, sedangkan sisanya sebesar $93,6 \%$ dipengaruhi oleh faktor lain yang tidak di teliti dalam penelitian ini.

\subsubsection{Uji Simultan (Uji F)}

Tabel 8

\begin{tabular}{lllllll}
\hline Model & & Sum of Squares & df & Mean Square & F & Sig. \\
\hline 1 & Regression & 1.389 & 2 & .695 & 4.159 & $.019 \mathrm{a}$ \\
& Residual & 15.032 & 90 & .167 & & \\
Total & 16.421 & 92 & & & \\
\hline
\end{tabular}

Berdasarkan tabel 8 menunjukan bahwa nilai $F_{\text {hitung }}=4,159$ dan $F_{\text {tabel }}=3,100$ sehingga diketahui nilai $F_{\text {hitung }}>F_{\text {tabel }}$, yaitu 4,159>3,100 dengan signifikansi $0,019<0,050$. Nilai signifikansi pengujian lebih kecil dari 0,050 menunjukan bahwa secara simultan economic performance dipengaruhi oleh variabel environmental performance dan environmental disclosure. Sehingga, model regresi pada penelitian ini dapat digunakan untuk memprediksi pengaruh variabel environmental performance dan variabel environmental disclosure terhadap variabel economic performance. 


\subsubsection{Uji Parsial (Uji t)}

Tabel 9

\begin{tabular}{|c|c|c|c|c|c|c|}
\hline \multirow[b]{2}{*}{ Model } & & \multicolumn{2}{|c|}{ Unstandardized Coefficients } & $\begin{array}{l}\text { Standardized } \\
\text { Coefficients }\end{array}$ & \multirow[b]{2}{*}{$t$} & \multirow[b]{2}{*}{ Sig. } \\
\hline & & $B$ & Std. Error & Beta & & \\
\hline \multirow[t]{3}{*}{1} & (Constant) & -.546 & .203 & & -2.694 & .008 \\
\hline & EnP & .153 & .058 & .269 & 2.640 & .010 \\
\hline & EnD & -.303 & .195 & -.158 & -1.551 & .124 \\
\hline
\end{tabular}

Dari uji statistik $t$ diperoleh nilai signifikansi variabel environmental performance sebesar 0,010<0,050, artinya bahwa variabel environmental performance secara parsial berpengaruh signifikan terhadap variabel economic performance. Sedangkan nilai signifikan dari variabel environmental disclosure sebesar 0,124>0,050 artinya bahwa variabel environmental disclosure secara parsial tidak berpengaruh signifikan terhadap economic performance.

\subsubsection{Pengujian Hipotesis}

\subsubsection{Pengujian Hipotesis Pertama}

Untuk mengetahui tingkat signifikansi koefisien korelasi pengaruh variabel environmental performance dan environmental disclosure terhadap variabel economic performance, maka akan di uji menggunakan uji F. Hasil uji $\mathrm{F}$ dapat di lihat dalam tabel 8. Berdasarkan tabel tersebut diketahui besarnya $F_{\text {hitung }}$ adalah sebesar 4,159 sedangkan nilai $F_{\text {tabel }}$ sebesar 3,100 sehingga diketahui $F_{\text {hitung }}>F_{\text {tabel }}$ yaitu 4,159>3,100, berarti Ho ditolak. Nilai signifikansi sebesar 0,019<0,050 yang berarti bahwa environmental performance dan environmental disclosure secara simultan berpengaruh signifikan terhadap economic performance., dengan demikian maka hipotesis pertama diterima.

\subsubsection{Pengujian Hipotesis Kedua}

Hasil uji statistik environmental performance pada tabel 9 diperoleh nilai thitung sebesar 2,640 sedangkan nilai $t_{\text {tabel }}$ sebesar 1,987 sehingga diketahui $t_{\text {hitung }}>t_{\text {tabel }}$ yaitu 2,640>1,987, berarti Ho ditolak. Nilai signifikansi sebesar $0,010<0,050$ ini berarti dapat disimpulkan bahwa environmental performance secara parsial berpengaruh signifikan terhadap economic performance, dengan demikian maka hipotesis kedua diterima.

Hasil pengujian hipotesis kedua tidak mendukung penelitian terdahulu, seperti hasil penelitian: Rachmawati dan Achmad (2012), Almilia dan Wijayanto (2007), Sarumpaet (2005) yang menemukan tidak adanya pengaruh signifikan variabel environmental performance terhadap economic performance. Namun hasil uji hipotesis kedua konsisten dengan penelitian: Suratno, Darsono dan Mutmainah (2006), 
Al-Tuwaijri (2004), Feedman dan Jaggi (1992), Spicer (1978), Bragdon dan Marlin (1972) yang menemukan hubungan signifikan antara environmental performance dengan economic performance.

\subsubsection{Pengujian Hipotesis Ketiga}

Hasil uji statistik environmental disclosure pada tabel 9 diperoleh nilai thitung sebesar -1,551 sedangkan nilai $t_{\text {tabel }}$ sebesar 1,987 . sehingga diketahui $t_{\text {tabel }} \leq t_{\text {hitung }} \leq t_{\text {tabel }}$ yaitu $-1,987 \leq-1,551 \leq 1,987$, berarti Ho diterima. Nilai signifikansi sebesar $0,124>0,050$ ini berarti dapat disimpulkan bahwa environmental disclosure secara parsial tidak berpengaruh signifikan terhadap economic performance, dengan demikian maka hipotesis ketiga ditolak.

Hasil pengujian hipotesis ketiga tidak mendukung penelitian terdahulu, penelitian terdahulu tersebut: Sudaryanto (2011), Almilia dan Wijayanto (2007), Al-Tuwaijri (2004) yang menemukan adanya pengaruh signifikan antara environmental disclosure dengan economic performance.

\section{KESIMPULAN DAN SARAN}

\subsection{Kesimpulan}

Dari hasil analisis diperoleh bukti bahwa secara simultan variabel environmental performance dan environmental disclosure berpengaruh signifikan terhadap variabel economic performance. Hasil uji statistik menunjukan bahwa PROPER mampu meningkatkan nilai economic performance, sedangkan environmental disclosure belum mampu menjelaskan economic performance.

\subsection{Saran}

Memperpanjang periode penelitian dan menggunakan metode cross section, memperhatikan data-data lain yang bisa digunakan sebagai dasar penilaian environmental performance, menambahkan variabel independen lainnya yang terkait dengan upaya penataan lingkungan hidup dan manajemen perusahaan (GCG, biaya riset, profit margin, firm size dan environmental concern), serta gunakan lebih dari satu media pelaporan dalam penilaian/check list environmental disclosure.

\section{DAFTAR PUSTAKA}

Akuntan Indonesia. 2007. Audit Lingkungan Suatu Keharusan?. Edisi No. 3, Tahun I, Hal. 17

Almilia, L.S. dan Wijayanto, D. 2007. Pengaruh Environmental Performance dan Environmental Disclosure Terhadap Economic Performance. Depok. The 1st Accounting Conference.

Al-Tuwaijri, S.A., Christensen, T.E. dan Hughes II, K.E. 2004. The Relations among Environmental Disclosure, Environmental Performance and Economic Performance: A Simultaneous Equations Approach. Accounting, Organizations and Society. Vol. 29. pp.447-471. 
Chariri, A. 2008. Kritik Sosial atas Pemakaian Teori dalam Penelitian Pengungkapan Sosial dan Lingkungan. Jurnal MAKSI, Vol. 8, No. 2, Agustus 2008. Hal 151-169.

Global Reporting Initiative (GRI). 2006. Reporting Guidelines G3.

CSR Indonesia 2012. Sinergi Pemerintah, Perusahaan dan Publik.

Heba, Y.M., and Yousef, M. 2010. Green accounting - a proposition for EA/ER conceptual implementation methodology. Journal of Sustainability and Green Business.

Hyrslova, J. and Hajek, M. 2006. Environmental accounting - an important part of an information system in the conditions when the company approach to the environment influences its prosperity. Vadyba / Management Nr. 3-4.

Imam Ghozali. 2005. Aplikasi Analisis Multivariate dengan Program SPSS. Edisi 3. Semarang: Badan Penerbit Universitas Diponegoro.

Kementrian Lingkungan Hidup Republik Indonesia, Program Penilaian Peringkat Kinerja Perusahaan dalam Pengelolaan Lingkungan Hidup (PROPER). http://www.menlh.go.id/proper/.

Lohman, L. 2009. Toward a different debate in environmental accounting: The cases of carbon and cost-benefit. Accounting, Organization and Society. Vol. 34.

M, Hasyim. 2011. Akuntansi Lingkungan: Apakah sebuah pilihan atau kewajiban?. Politeknik Negeri Ujung Pandang.

Rahahleh, M.Y. 2011. Means for Implementation of Environmental Accounting Jordanian Perspectives. International Journal of Business and Management, Vol. 6, No. 3, March 2011.

Rahmawati, A. dan Achmad, T. 2012. Pengaruh Kinerja Lingkungan Terhadap Financial Corporate Performance dengan Corporate Social Responsibility Disclosure sebagai Variabel Intervening. Diponegoro Journal of Accounting, Vol. 1, No. 2, tahun 2012. hal 1-15.

Sarumpaet, S. 2005. The Relationship between Environmental Performance and Financial Performance of Indonesian Companies. Jurnal Akuntansi \& Keuangan, Vol. 7, No. 2, November 2005.

Soelarno, S.W. 2006. Pertambangan Sebagai Aset bangsa Indonesia. Indonesian Journal for Sustainable Future Vol. 2, No. 4. Hal. 57-73.

Sudariyono. 2006. Nasionalisme Lingkungan Wujud Kesadaran Kolektif Nasional. Indonesian Journal for Sustainable Future Vol. 2, No. 4. Hal. 27-37.

Sulistomo, HM. B. 2005. Kemiskinan Nasional dan Kedaulatan Rakyat. Indonesian Journal For Sustainable Future Vol. 1 No. 1.

Suratno, I.B., Darsono dan Mutmainah, S. 2007. Pengaruh Environmental Performance Terhadap Environmental Disclosure dan Economic Performance. Jurnal Riset Akuntansi Indonesia, Vol. 10, No. 2, Mei 2007. Hal 199-214. 
Undang-Undang Republik Indonesia nomor 40 Tahun 2007 tentang Perseroan Terbatas. Pasal 74.

Utami, S. dan Prastiti, S.D. 2011. Pengaruh Karakteristik Perusahaan Terhadap Social Disclosure. Jurnal Ekonomi Bisnis, TH. 16, No. 1, Maret 2011.

www.idx.co.id//(Data terkait annual report dan ringkasan kinerja perusahaan tercatat).

Zaenuddin, A. 2007. Faktor-Faktor yang Berpengaruh Terhadap Praktek Pengungkapan Sosial dan Lingkungan pada Perusahaan Manufaktur Go Public. Tesis. Fakultas Ekonomi Universitas Diponegoro Semarang. 